\title{
INVESTIGATION OF TECHNICAL CHARACTERISTICS OF THERMOELECTRIC ADD-ON FOR PRESSURE JET BURNERS
}

\author{
Vladimir Ezhov* \\ South-West State University, Kursk, Russia \\ Natalya Semicheva \\ South-West State University, Kursk, Russia \\ Sergey Berezin \\ South-West State University, Kursk, Russia \\ Vasiliy Amelin \\ South-West State University, Kursk, Russia \\ Alexey Burtsev \\ South-West State University, Kursk, Russia
}

This article is dedicated to problems of simultaneous generating of both thermal and electric power using thermoelectric effect of working pressure jet burner. A pilot plant description, study methods and results of the experiment are given below. Possibility of electric power generating with using thermoelectric add-on for utility pressure jet burners is also displayed below.

Key words: Thermoelectricity; Thermoelectric effect; Recycling; Energy; Power generator; Pressure jet burner

\section{INTRODUCTION}

One of the most important fields of energy saving in city housing and communal services is collateral electric power generating during thermal power producing. This phenomenon is physically based on the Seebeck effect (thermoelectric effect), which means originating of thermal emf initiated by heating up of junction of two dissimilar metals or of two semi-conductors (thermocouple). Thermal emf tension (ET emf) is in direct relation to the Seebeck coefficient $\alpha$ and to the temperature difference $\Delta T$ between hot and cold sides (junctions) of the thermoelectric module. Thermoelectric generating is one of the most advanced ways to converse thermal power into electric power, and in some cases it is the only obtainable way. What is more important, that such direct conversion excludes intermediate steps, like in a nuclear or thermal power plant working process, where thermal power converses into mechanical power and only then mechanical power converses into electric power [01, 02].

\section{CONVERSION OF THERMAL POWER INTO ELECTRIC POWER IN THERMOELECTRIC ADD-ON FOR PRESSURE JET BURNER}

Direct conversion of heat into electric power is favorable particularly in Russia with its' large area (North of Russia, Siberia, Far East), which cannot be provided with stationary electric power sources. Successful solution of these city housing and communal services' problems will allow thermal and electric power costs reducing, ecological situation improving and making safety conditions of citizens' life better. The Heat, Gas and Water Supply Department in South-West State University suggested technological solutions of thermoelectric effect using in pressure jet burners [03, 04] and made laboratory studies on structure of technological solution called "Electrical generator and Burner". The study revealed that thermionic converters can be used as the main structure element of pressure jet burners for collateral electric energy generating during heat producing. Thermionic converters involve coupled wire sections made of metals M1 (chromel) and M2 (copel: $\mathrm{Cu}, \mathrm{Ni}, \mathrm{Mn}$ ). The use of 
these metals and wide applying of thermal generators significantly reduce the prime cost of a thermal generator and increases its reliability [5, p. 265-270; 6, p. 122-127]. According to the study an electric power producing add-on for the pressure jet burner was developed. The distinctive feature of the add-on structure is the certain arraignment of add-on components placed around the pressure jet burner. The support ring is made of dielectric material with legs. The thermoelectric section consisting of thermal emissive converters is put on the ring. Coupled M1 and M2 sections of the converters are bent at right angle underneath, the ends of these sections are soldered or welded with each other, forming a zigzag row, which creates a disconnected circle outline. The circular shield representing a flat ring made of dielectric material with stanchions is attached to the zigzag row. Furthermore, legs and stanchions of the support ring, the zigzag row and the circular shield are installed on a work surface of a gas stove. The circular shield divides the zigzag row by the horizon into a hot zone and a cold zone. The length of the metal (M1 and M2) sections' bent ends should meet several conditions: the upper junctions of the zigzag row should be located in the jet base zone; the lower junctions of the row should be located near the work surface of the gas stove; the current terminals of thermoelectric section should be attached to the collector with similar charges, connected with the convertor, which produces required tension and current. According to research a pilot plant was designed as well. The main structure elements of the pilot plant are the utility pressure jet burner and the electric power generating add-on comprising zigzag row of thermal emissive elements made of bare chromel and copel wires, which are soldered with each other by the ends and have lower ends bent at right angle. The circuitry of the pilot plant (the pressure jet burner improved with electricity generating add-on) is shown on Figure 1. Thermoelectric effect underpins the working principle of the developed pressure jet burner add-on producing electricity. Since the thermoelectric section (3) is built in the form of zigzag rows 8 assembled from coupled wire sections 5 and 6 , which are made of metals M1 and M2 and soldered (welded) with each other by the ends, different temperatures are set on the opposite junctions of coupled wire sections 5 and 6 while heating the first soldered ends 5 and 6 and cooling the opposite soldered ends of thermionic converter 4 situated in the cold zone 17 near the work surface 11 . In the connection zone (junction 7) of metals M1 and M2 thermal emission of electrons occurs, causing the electric power generating in zigzag rows 8 of the thermionic converter 3 [7, c. 502-506]. Electric generating add-on for pressure jet burner work process occurs in such way. Preparatory the elements of add-on are installed on the pressure jet burner 12. Firstly the support ring 1 is installed on the work surface 11 of the gas-stave (not shown in Figure 1) so that the burner body 12 is situated right in the middle of the ring 1 and then the ring is fixed on the surface 11 (attaching lugs are not shown in Figure 1). Then thermoelectric section 3 is installed on the ring 1 , the circular shield is put on the thermoelectric section 3 . The shield is installed on the work surface 11 with use of stanchions 10 and fixed (attachment lugs are not shown in Figure 1). Primary air is sucked up over the work surface of the stave through the gap between the burner body 12 and the crown 14 . The body of the burner 12 is connected to the pulverizer 13, which injects gas, and primary air is mostly sucked up into the crown of the burner due to rubbing with gas stream. The jagged crown 14 of the burner has a lot of radial potholes (flame canals), so the mixture of gas and air torched with the glow plug 16 gets outside in radial direction creating a circular jet. The lid 15 covers the burner and with the help of the crown 14 of the burner defines the size of flame canals. Flame stability and combustion quality growth around the body of the burner occurs due to the circular canal formed by the zigzag row 8 , the thermionic converter 4 , the thermoelectric section 3 and the circular shield 9. Through the circular shield heated secondary air is sucked up from the cold zone 17 into the hot zone 18 and then into the combustion zone. This air simultaneously cools the lower soldered ends of the thermionic converter 4 and the thermoelectric section 3 in the cold zone. At the same time while heating soldered ends of wire sections 5 and 6 and cooling in the jet base by the lid 15 (hot zone 18) and cooling the opposite soldered ends of the thermionic converter 4 (cold zone 17), different temperatures on the opposite junctions of the coupled wire sections are installed. In the junction 7 of metals M1 and M2 thermal emission of electrons occurs which causes the thermal electricity producing in the zigzag row 8 of the thermoelectric section 3 . Generated thermoelectric power is received into 
the collectors with similar charges through the terminals 19 and 20, then into the convertors (not shown on Figure 1), where required voltage is created and then applied to consumers.

\section{RESULTS OF THE EXPERIMENTAL STUDY}

Experimental study were pursued with the conditions and using of the equipment listed below:

Pressure jet burner - 1 unit

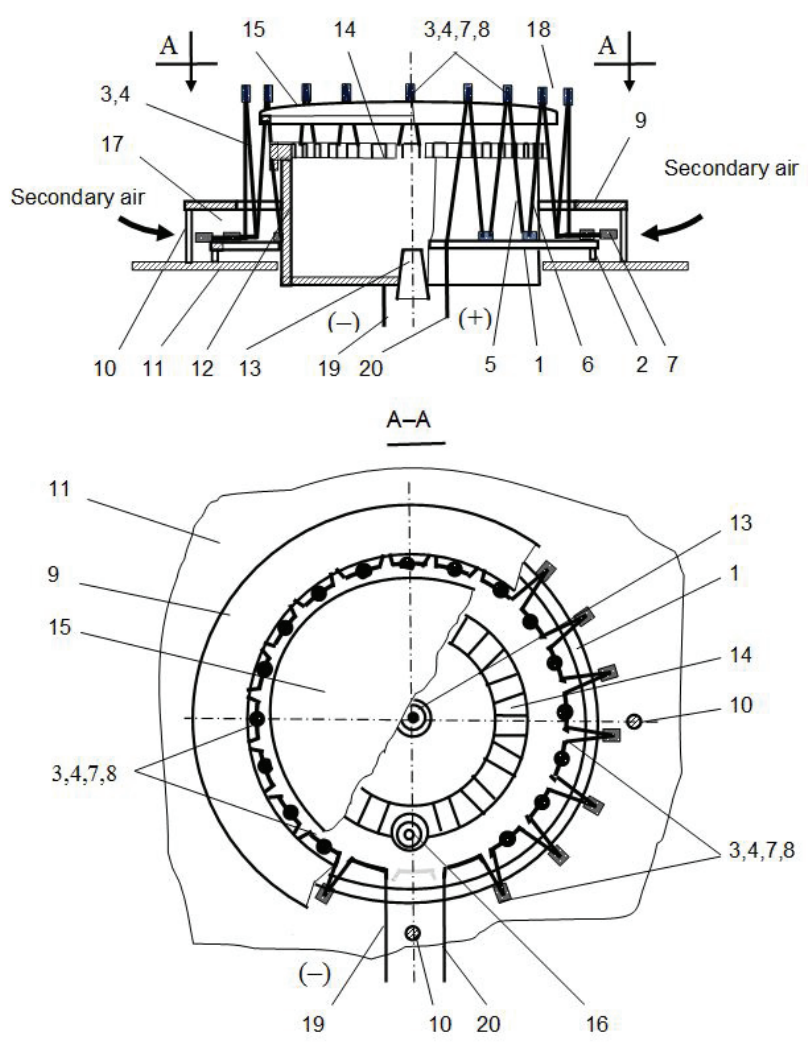

Figure 1: Circuit of the pilot plant: 1 - support ring; 2 -legs; 3 - thermoelectric section; 4 - thermionic converter; 5,6 - coupled sections; 7 - junction; 8 - zigzag row, 9 - circular shield; 10 - stanchions; 11 - work surface of a gas stove; 12 - pressure jet burner; 13 - gas injector; 14 - jagged crown; 15 - lid; 16 - glow plug; 17,18 - hot ans cold zones; 19,20 - current terminals

Pyrometer (highly-precise remote-sensing infrared thermometer) AR 872A (measurement range $180 \mathrm{C}-15000 \mathrm{C})-1$ unit

\section{Thermoelectric add-on - 1 unit}

Thermoelectric section 8 structure characteristics: number of thermionic converters 9 in thermoelectric section $8=70$ units. Overall length of wire sections $10,11(\mathrm{M} 1, \mathrm{M} 2)=100 \mathrm{~mm}$, length of bended wire sections in the cold zone $=40 \mathrm{~mm}$, wire section diameter $(10,11)=0,6 \mathrm{~mm}$.

Fuel characteristics: gas from the portable cylinder was used as a fuel, comprising butane $(70 \%)$ and propane (30\%) $\mathrm{QPH}=94800 \mathrm{~kJ} / \mathrm{m} 3$

Study conditions: surrounding air temperature was $200 \mathrm{C}$. Thermal load was changed by changing gas flow. Experiment results are presented in Table 1 and in Figure 2. Investigation of technical characteristics of thermoelectric add-on for pressure jet burners was part of the one-year phase of the research work №3825 "Study on direct conversion of thermal power into electric power in jet burner" which is a basic component of state demand in academic activity.

\section{CONCLUSION}

Experimental data confirm the results of previous researches on pressure jet burner, which is an electric generator at the same time. In pressure jet burners for thermoelectricity generation a thermionic converter consisting of coupled wire sectors made of metals M1 (chromel) and M2 (copel) can be used as the basic constructive component. Experiment results show that correlation electric power, tension and current with squared difference of temperatures is a curve (exponent). Study on electric generating add-on for pressure jet burner showed its' great advance in current and electric power when compared to the previous structure of electric generator burner. 
Table 1: Experiment results

\begin{tabular}{|c|c|c|c|c|c|c|}
\hline № $\Pi / \Pi$ & $\begin{array}{c}\text { Hot junction } \\
\text { temperature } \\
\left(T_{n}\right),{ }^{0} \mathrm{C}\end{array}$ & $\begin{array}{l}\text { Cold junction } \\
\text { temperature }\left(T_{c}\right) \text {, } \\
{ }^{0} \mathrm{C}\end{array}$ & $\begin{array}{c}\text { Temperature } \\
\text { difference } \\
(\Delta \mathrm{T}),{ }^{\circ} \mathrm{C}\end{array}$ & Viltage,V & $\begin{array}{c}\text { Current, } \\
\mathrm{mA}\end{array}$ & Electric power, W \\
\hline 1 & 2 & 3 & 4 & 5 & 6 & 7 \\
\hline 1 & 400 & 40 & 360 & 1,05 & 100 & 0,105 \\
\hline 2 & 450 & 40 & 410 & 1,15 & 130 & 0,145 \\
\hline 3 & 500 & 40 & 460 & 1,3 & 170 & 0,221 \\
\hline 4 & 550 & 42 & 508 & 1,45 & 230 & 0,334 \\
\hline 5 & 600 & 42 & 552 & 1,65 & 300 & 0,493 \\
\hline 6 & 650 & 42 & 607 & 1,85 & 380 & 0,700 \\
\hline 7 & 700 & 43 & 657 & 2,05 & 470 & 0,975 \\
\hline 8 & 750 & 43 & 707 & 2,3 & 570 & 1,30 \\
\hline 9 & 800 & 43 & 757 & 2,6 & 680 & 1,76 \\
\hline 10 & 850 & 45 & 805 & 2,8 & 800 & 2,13 \\
\hline
\end{tabular}



Figure 2: Correlation of electric capacity $(W)$, tension $(V)$ and current $(A)$ with squared difference of temperatures $(\Delta T)$ (experimental data): $O$ - electric power; $X$ - tension (voltage); $\Delta$-current

\section{REFERENCES}

1) Goldsmit G. Primeneniya termoelektrichestva / Per. s angl. pod red. A. F. Chudnovskogo. M.: Fizmatgiz, 1963.

2) Ohotin A. S., Efremov A. A., Ohotin V. S., Pushkarskiy A. S. Termoelektricheskie generatoryi. M.: Atomizdat, 1971.

3) Zayavka na izobr. RF \# 2015119415, GoreIka-elektrogenerator/ Ezhov V.S., Berezin, S.V., Berezin D.S., 2015.

4) Zayavka na izobr. RF \# 2015144497, Elektrogeneriruyuschaya pristavka dlya inzhektsionnoy gorelki/ Ezhov V.S., Semicheva N.E., Berezin S.V., Burtsev A.P., Berezin D.S., 2015.

5) Direct Heat Energy Conversion Into Electrical Energy: An Experimental Study / Vladimir Yezhov, Sergey Yemelianov, Natalia Semicheva, Sergey Berezin, Alexey Burtsev, Valeria Tolmachyova/ Journal of Applied Engi- neering Science, Paper number: 13(2015)4, 339, P. $265-270$.

6) Poluchenie elektricheskoy energii pri rabote inzhektsionnoy gorelki (tezisyi doklada)/ Ezhov V.S., Semicheva N.E., Burtsev A.P./ Molodoy inzhener - osnova nauchnotehnicheskogo progressa: Sbornik nauchnyih trudov Mezhdunarodnoy nauchno-tehnicheskoy konferentsii (9-10 oktyabrya 2015 goda). Yugo-Zap. gos. un-t. - Kursk, 2015. - 418 s.- S. 122-127. ISBN 978-5-9907150-3-5.

7) Kalashnikov S.G. Elektrichestvo [Tekst] S.G. Kalashnikov - M.: Nauka, 1970.

Paper sent to revision: 30.09.2016

Paper ready for publication: 04.12.2016. 